\title{
PENGARUH PEMBERIAN JUS BUNCIS TERHADAP PENURUNAN KADAR KOLESTEROL DI PUSKESMAS BENDA BARU KOTA TANGERANG SELATAN
}

\author{
${ }^{1}$ Ida Listiana, ${ }^{2}$ Fenita Purnama, ${ }^{3}$ Ardina Sholeha \\ ${ }^{1,3}$ Program Studi D3 Kebidanan STIKes Widya Dharma Husada Tangerang, \\ ${ }^{2}$ Program Studi S1 Kesehatan Masyarakat STIKes Kharisma Persada, \\ ${ }^{1}$ Email : idalistiana8@gmail.com
}

\begin{abstract}
ABSTRAK
Latar Belakang: Prevalensi hiperlipidemia (kolesterol tinggi) di Indonesia meningkat dari tahun ke tahun. Pada tahun 2013 prevalensi sebesar 35,9\% (WHO 2013). Seiring dengan perkembangan zaman masyarakat cenderung memiliki perilaku konsumsi makanan berisiko. Prevalensi penduduk Indonesia dengan perilaku konsumsi makanan berisiko (makanan berlemak, berkolesterol, dan gorengan) lebih dari atau sama dengan satu kali per hari $40,7 \%$. Banten merupakan provinsi tertinggi kelima perilaku konsumsi makanan berlemak yaitu sebanyak 48,8\%. Tujuan Penelitian untuk mengetahui adakah pengaruh pemberian jus buncis terhadap penurunan kadar kolesterol di Puskesmas Benda Baru Kota Tangerang Selatan. Metode penelitian ini pre-eksperimen (percobaan/perlakuan) dengan pendekatan pre and post one the group tanpa kelompok pembanding dan tanpa kelompok kontrol. Sampel penelitian ini pada pasien tinggi kolesterol di Puskesmas Benda Baru Kota Tangerang Selatan. Hasil penelitian ini dilakukan terhadap 11 responden dengan pemberian jus buncis. Hasil penelitian ini menunjukkan bahwa hampir setengahnya responden dengan kategori batas tinggi yaitu sebanyak 4 responden (36,4\%), dan lebih dari setengahnya responden dengan kategori tinggi yaitu sebanyak 7 responden (63,3\%). Dan hasil penelitian setelah diberikan intervensi didapatkan bahwa menunjukkan bahwa sebagian besar responden dengan kategori normal yaitu sebanyak 10 responden (90,0\%), dan sebagian kecil responden dengan kategori batas tinggi sebanyak 1 responden $(9,1 \%)$. Berdasarkan uji Willcoxon, didapatkan $p$ value $0,003(\alpha<0,05)$ yang dapat disimpulkan bahwa ada pengaruh yang signifikan dengan mengkonsumsi jus buncis terhadap penurunan kadar kolesterol.
\end{abstract}

Kata kunci : Jus Buncis, Kolesterol

\begin{abstract}
Background: The prevalence of hyperlipidemia (high cholesterol) in Indonesia has increased from year to year. In 2013 the prevalence was 35.9\% (WHO 2013). Along with the times, people tend to have risky food consumption behavior. The prevalence of Indonesian population with risky food consumption behavior (fatty, cholesterol and fried foods) is more than or equal to once per day 40.7\%. Banten is the fifth highest province of fatty food consumption behavior that is as much as $48.8 \%$. The Method of this research pre-eksperimen ( experiment / treatment) with the approach pre and post one the group without the comparison group and without the control group. Research sample areas on a patient high cholesterol at puskesmas new objects South Tangerang. The Result of this research was conducted on 11 respondents by administering juice. Beans this research result indicates that nearly half of respondents with category a height requirement which is as much as 4 respondents (36,4\%), and more than half of respondents with high category which is as much as 7 respondents (63,3\%). And the research results after being granted an intervention got that shows that most respondents with categories normal that is as much as 10 respondents (90,0\%), and a small number with elevated borders category as many as 1 respondents $(9,1 \%)$. Based on the willcoxon, got that any impact on reductions in the juice beans cholesterol levels by $p$ value , $003 \&$ it; a (0,05) that could be observed that there are significant influence they consume juice beans to a decrease in cholesterol levels..
\end{abstract}

Keywords: Juice Beans, Cholesterol 


\section{PENDAHULUAN}

Hiperlipidemia (kolesterol tinggi) menjadi faktor utama penyebab aterosklerosis. Prevalensi hiperlipidemia di Indonesia meningkat dari tahun ke tahun. Pada tahun 2008 tercatat sebesar $35,1 \%$. Kemudian pada tahun 2013 meningkat menjadi 35,9\% (WHO 2013). Seiring dengan perkembangan zaman masyarakat cenderung memiliki perilaku konsumsi makanan berisiko. Salah satunya mengkonsumsi makanan berlemak, berkolesterol, dan gorengan.

Prevalensi penduduk Indonesia dengan perilaku konsumsi makanan berlemak, berkolesterol, dan gorengan lebih dari atau sama dengan satu kali per hari 40,7\%. Lima provinsi tertinggi dengan perilaku konsumsi makanan berlemak yaitu provinsi Jawa Tengah (60,3\%), DI Yogyakarta (50,7\%), Jawa Barat $(50,1 \%)$, Jawa Timur $(49,5 \%)$, dan Banten sebanyak 48,8\%, oleh karena itu proporsi penduduk Indonesia dengan kadar kolesterol di atas normal lebih tinggi pada perempuan yaitu sebesar 39,6\% jika dibandingkan dengan lakilaki sebesar 30\% (Riskesdas, 2013).

Kadar kolesterol yang tinggi merupakan salah satu penyebab masalah metabolik yang menyebabkan timbulnya penyakit jantung, pembuluh darah, serta penyakit-penyakit yang berhubungan dengan adanya sumbatan pada pembuluh darah.
Adanya penumpukan jumlah deposit lemak pada dinding pembuluh darah dapat menyebabkan suatu sumbatan pembuluh darah atau yang dikenal sebagai aterosklerosis (Rizky, 2013).

Terdapat pula pengobatan farmakologis dan non farmakologis. Pengobatan farmakologis yaitu pengobatan yang dengan menggunakan obat-obatan yang mengandung zat kimia didalamnya, sedangkan pengobatan non farmakologis yaitu pengobatan dengan tidak menggunakan obatobatan dan biasanya pengobatan ini lebih menggunakan bahan-bahan herbal karena tidak memiliki efek samping dalam tubuh, dan tanaman obat yang digunakan lebih mudah diperoleh dengan harga yang cukup murah.

Pengobatan tradisional dilakukan dengan menggunakan tanaman obat yang sudah dikenal dan digunakan oleh nenek moyang kita sebagai warisan turun temurun (UU RI No. 23/1992). Masih banyak masyarakat Indonesia yang memanfaatkan tanaman sebagai obat untuk mengatasi berbagai penyakit dalam meningkatkan kesehatan, salah satunya adalah buncis (Phaseolus Vulgaris L.). Buncis ini dipercaya dapat menurunkan kadar kolesterol, karena dengan kandungan flavonoid di dalam buncis tersebut sehingga dapat menurunkan kadar kolesterol darah (Kissanti, 2013). 
Tujuan penelitian ini adalah 1) untuk mengidentifikasi karakteristik berdasarkan usia dan jenis kelamin pada penderita kolesterol di Puskesmas Benda Baru Kota Tangerang Selatan, 2) untuk mengidentifikasi kadar kolesterol sebelum diberikan jus buncis di Puskesmas Benda Baru Kota Tangerang Selatan, 3) untuk mengidentifikasi kadar kolesterol setelah diberikan jus buncis di Puskesmas Benda Baru Kota Tangerang Selatan, 4) adakah Pengaruh pemberian jus buncis terhadap penurunan kadar kolesterol di Puskesmas Benda Baru Kota Tangerang Selatan.

Berdasarkan data dan fakta diatas peneliti tertarik untuk meneliti adakah pengaruh pemberian jus buncis terhadap penurunan kadar kolesterol di Puskesmas Benda Baru Kota Tangerang Selatan tahun 2019.

\section{METODE}

Penelitian ini menggunakan preeksperimen dalam kelompok eksperimen berupa percobaan / perlakuan yang bertujuan untuk mengetahui suatu gejala atau pengaruh yang timbul sebagai akibat dari adanya perlakuan tertentu terhadap suatu subjek yang mendapat perlakuan. Desain penelitian ini menggunakan One-Group Pretest-Posttest Designtanpa menggunakan kelompok pembanding (kontrol).

Populasi dalam penelitian ini adalah pasien kolesterol di puskesmas benda baru yang berkunjung dalam bulan Januari sampai dengan Maret 2019 yang secara keseluruhan berjumlah 28 orang. Pengambilan sampel pada penelitian ini menggunakan metode non probability sampling dengan teknik purposive sampling. Instrumen yang digunakan dalam penelitian ini adalah alat Easy Touch dan lembar observasi yang digunakan untuk mencatat karakteristik responden yang meliputi nama responden, usia, dan jenis kelamin. Dan digunakan juga untuk mencatat pengukuran kadar kolesterol darah sebelum dan sesudah intervensi.

Pengumpulan data dilaksanakan di rumah responden, setelah responden menyetujui lembar persetujuan maka peneliti dan responden membuat kesepakatan hari dan waktu melakukan tindakan. Pada penelitian ini tindakan pengukuran dan terapi pemberian jus buncis dilakukan setiap hari sekali $3 / 4$ gelas, sebelum dilakukan terapi pemberian jus buncis peneliti mengukur kolesterol responden, setelah pengukuran kadar kolesterol, peneliti melakukan tindakan pemberian jus buncis dilakukan setiap hari sekali 3/4 gelas dalam 14 hari, setelah meminum terapi pemberian jus buncis selesai, peneliti melakukan pengukuran kadar kolesterol di hari ke 14.

Penelitian ini menganalisis distribusi frekuensi karakteristik responden yaitu usia dan jenis kelamin. Analisis bivariat pada penelitian ini adalah uji statistik terhadap rata- 
rata perbedaan kadar kolesterol antara sebelum dan setelah pemberian jus buncis dari tahap pertama dan tahap-tahap berikutnya dengan menggunakan uji willcoxon test. Penelitian ini sesuai dengan etik penelitian yaitu penelitian yang dihasilkan dapat memberikan manfaat dan mempertimbangkan antara aspek resiko dengan aspek manfaat, bila penelitian yang dilakukan dapat mengalami dilema dalam etik, manusia memiliki hak dan merupakan makhluk yang mulia yang harus dihormati, karena manusia untuk diikutsertakan menjadi subjek penelitian, menghargai hak atau memberikan pengobatan secara adil, hak menjaga privasi manusia, dan tidak berpihak dalam perlakuan terhadap manusia.

Tabel 1. Distribusi Frekuensi Responden Berdasarkan Usia dan Jenis Kelamin

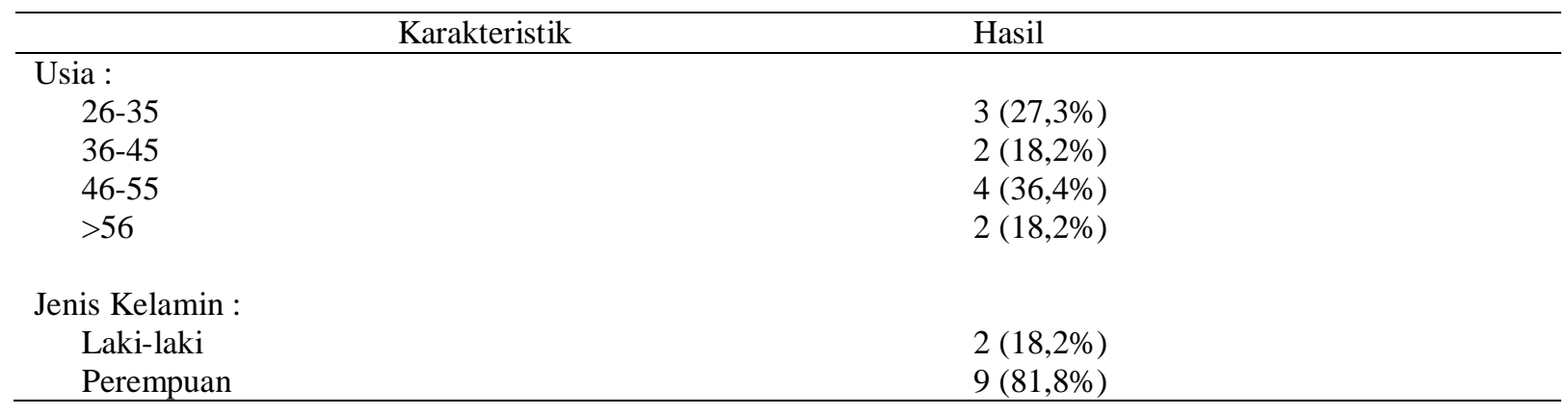

Tabel 2. Distribusi Frekuensi Kadar Kolesterol Sebelum Diberikan Jus Buncis Di Puskesmas Benda Baru Kota Tangerang Selatan $(\mathrm{n}=11)$

\begin{tabular}{|c|c|c|c|c|c|c|}
\hline Variabel & Kategori & $\mathbf{N}$ & $\%$ & Mean & Min & Max \\
\hline \multirow{4}{*}{$\begin{array}{ll}\text { Kadar } & \text { kolesterol } \\
\text { sebelum } & \text { diberikan } \\
\text { jus buncis } & \end{array}$} & Normal & - & $0 \%$ & 256,64 & 230 & 287 \\
\hline & Batas Tinggi & 4 & $36,4 \%$ & & & \\
\hline & & 7 & $63,6 \%$ & & & \\
\hline & & 11 & 100 & & & \\
\hline
\end{tabular}

Tabel 3. Distribusi Frekuensi Kadar Kolesterol Setelah Diberikan Jus Buncis Di Puskesmas Benda Baru Kota Tangerang Selatan $(\mathrm{n}=11)$

\begin{tabular}{llccccc}
\hline \multicolumn{1}{c}{ Variabel } & \multicolumn{1}{c}{ Kategori } & N & \% & Mean & Min & Max \\
\hline $\begin{array}{l}\text { Kadar kolesterol } \\
\text { setelah diberikan jus } \\
\text { buncis }\end{array}$ & Normal & 10 & $90,0 \%$ & 163,91 & 136 & 203 \\
& $\begin{array}{l}\text { Batas Tinggi } \\
\text { Tinggi }\end{array}$ & 1 & $9,1 \%$ & & & \\
& & - & $0 \%$ & & & \\
\hline
\end{tabular}


Tabel 4. Pengaruh Pemberian Jus Buncis Terhadap Penurunan Kadar Kolesterol Dipuskesmas Benda Baru Kota Tangerang Selatan $(n=11)$

\begin{tabular}{|c|c|c|c|c|c|c|c|}
\hline \multirow[t]{2}{*}{ Kategori } & \multicolumn{6}{|c|}{ Pemberian jus buncis pada penurunan kadar kolesterol } & \multirow[t]{2}{*}{ p-value } \\
\hline & Pre & $\mathbf{N}$ & $\%$ & Post & $\mathbf{N}$ & $\%$ & \\
\hline Normal & - & 11 & $0 \%$ & 10 & 11 & $90,0 \%$ & \\
\hline Batas Tinggi & 4 & & $36,4 \%$ & 1 & & $9,1 \%$ & \\
\hline Tinggi & 7 & & $63,6 \%$ & - & & $0 \%$ & \\
\hline Rerata & 256,64 & & & 163,91 & & & 0,003 \\
\hline $\begin{array}{l}\text { Penurunan Rerata } \\
\text { nilai kadar kolesterol }\end{array}$ & & & 66,00 & & & & \\
\hline Min & 230 & & & 136 & & & \\
\hline Max & 287 & & & 203 & & & \\
\hline
\end{tabular}

\section{HASIL PENELITIAN}

Tabel 1 menjelaskan bahwa distribusi frekuensi usia menunjukkan bahwa hampir setengahnya dengan usia 26-35 tahun yaitu sebanyak 3 responden $(27,3 \%)$, sebagian kecil dengan usia 36-45 tahun yaitu sebanyak 2 responden $(18,2 \%)$, hampir setengahnya dengan usia 46-55 tahun yaitu sebanyak 4 responden (36,4\%), dan sebagian kecil dengan usia $>56$ tahun yaitu sebanyak 2 responden (18,2\%), dengan usia minimumnya yaitu 26 dan usia maximumnya yaitu $>56$.

Distribusi frekuensi jenis kelamin menunjukkan bahwa sebagian besar responden dengan jenis kelamin perempuan yaitu sebanyak 9 responden $(81,8 \%)$, dan sebagian kecil responden dengan jenis kelamin laki-laki sebanyak 2 responden (18,2\%).

Tabel 2 distribusi frekuensi berdasarkan kadar kolesterol sebelum pemberian jus buncis, dari 11 responden menunjukkan bahwa bahwa sebagian besar responden dengan jenis kelamin perempuan yaitu sebanyak 9 responden $(81,8 \%)$, dan sebagian kecil responden dengan jenis kelamin laki-laki sebanyak 2 responden $(18,2 \%)$.

Tabel 3 distribusi frekuensi berdasarkan kadar kolesterol setelah pemberian jus buncis, dari 11 responden menunjukkan bahwa sebagian besar responden dengan kategori normal yaitu sebanyak 10 responden $(90,0 \%)$, dan sebagian kecil responden dengan kategori batas tinggi sebanyak 1 responden $(9,1 \%)$. Dengan nilai kadar kolesterol minimum 136 mg/dl dan maximum 203 mg/dl dengan rata-rata kadar kolesterol 163,91 mg/dl. 
Tabel 4 dapat diketahui nilai kadar kolesterol sebelum diberikan jus buncis dari 11 responden, terdapat 4 responden $(36,4 \%)$ yang berada dikategori batas tinggi dan 7 responden $(63,6 \%)$ yang berada dikategori tinggi, dengan nilai minimum $230 \mathrm{mg} / \mathrm{dl}$ dan maximum yaitu 287 mg/dl dengan rerata nilai kadar kolesterol $256,64 \mathrm{mg} / \mathrm{dl}$ yang berarti termasuk dalam kategori kolesterol tinggi, sedangkan setelah diberikan jus buncis dari 11 responden terdapat 10 responden $(90,0 \%)$ yang kadar kolesterolnya berada dikategori normal dan 1 responden $(9,1 \%)$ yang kadar kolesterolnya masih berada dikategori batas tinggi dengan nilai minimum $136 \mathrm{mg} / \mathrm{dl}$ dan maximum 203 mg/dl dengan rerata nilai kadar kolesterol $163,91 \mathrm{mg} / \mathrm{dl}$ yang berarti termasuk kedalam kategori normal. Berdasarkan uji willcoxon, didapatkan bahwa terdapat adanya pengaruh jus buncis terhadap penurunan kadar kolesterol sebelum dan setelah diberikan jus buncis, dengan nilai $\mathrm{p}$-value $0,003<\mathrm{a}(0,05)$.

\section{PEMBAHASAN}

Tabel 1 menjelaskan bahwa hampir setengahnya usia responden sebanyak 4 pada usia 46-55 tahun (36,4\%), menurut Graha, 2010 kadar kolesterol pada perempuan dan laki-laki secara alami meningkat seiring bertambahnya usia (45-55 tahun), menopause sering dikaitkan dengan peningkatan kolesterol LDL pada perempuan dan semakin lanjut usia seseorang risiko memiliki kolesterol tinggi pun akan semakin meningkat. Biasanya pada orang yang berusia $>55$ tahun memiliki kadar kolesterol LDL yang berlebih sehingga memungkinkan risiko terkena kolesterol tinggi pun makin besar.

Sedangkan untuk distribusi frekuensi jenis kelamin didapatkan responden sebagian besar berjenis kelamin perempuan yaitu sebanyak 9 orang $(81,8 \%)$. Responden yang mempunyai kadar kolesterol tinggi paling besar berjenis kelamin perempuan, menurut Veronika, 2016 seiring dengan perkembangan zaman masyarakat cenderung memiliki perilaku konsumsi makanan berisiko. Salah satunya mengkonsumsi makanan berlemak, berkolesterol, dan gorengan. Prevalensi penduduk Indonesia dengan perilaku konsumsi makanan berlemak, berkolesterol, dan gorengan lebih dari atau sama dengan satu kali per hari 40,7 .

Oleh karena itu proporsi penduduk Indonesia dengan kadar kolesterol di atas normal lebih tinggi pada perempuan yaitu sebesar 39,6\% jika dibandingkan dengan lakilaki sebesar 30\% (Riskesdas, 2013).

Tabel 2 Kadar kolesterol dalam tubuh dinyatakan normal pada saat kadar kolesterol total kurang dari $200 \mathrm{mg} / \mathrm{dl}$. Sementara, kolesterol HDL 35-65 mg/dl dan kolesterol LDL kurang dari 150 mg/dl. Kolesterol pada kadar normal merupakan komponen utama pembentuk dinding sel, empedu, dan hormon 
seperti hormon seks. Fungsi lainnya adalah pembentuk asam dan garam empedu yang berfungsi untuk mengemulsi lemak serta pembentuk vitamin D yang penting untuk tulang. Senyawa ini juga berfungsi memecah lemak dan berperan pada penyaluran impuls syaraf. Juga sebagai pembungkus jaringan saraf dan membantu perkembangan sel-sel otak pada anak (Herliana, 2009).

Tabel 3 Menurut Rimbawan, 2013 hiperkolesterolemia dapat meningkatkan resiko terkena penyakit kardiovaskuler. Hiperkolesterolemia adalah suatu kondisi dimana kadar kolesterol darah melebihi 250 $\mathrm{mg} / \mathrm{dl}$. Prevalensi hiperkolesterolemia di Indonesia rentang umur 25-65 tahun menurut survei Konsumsi Rumah Tangga (SKRT) 2004 adalah sebesar 1,5\% dan prevalensi batas tinggi (kadar kolesterol darah 200-249 mg/dl) adalah sebesar 11,2\%. Kelompok batas tinggi dapat menjadi hiperkolesterolemia apabila tidak menjaga pola hidup sehat dan seimbang.

Tabel 4 Pengaruh Pemberian Jus Buncis Terhadap Penurunan Kadar Kolesterol Di Puskesmas Benda Baru Kota Tangerang Selatan. Berdasarkan hasil dari penelitian yang didapat sebelum pemberian jus buncis didapatkan hasil dari 11 responden yang termasuk kedalam penelitian ini terdapat 4 responden $(36,4 \%)$ yang kadar kolesterolnya menduduki kategori batas tinggi sedangkan 7 responden $(63,6 \%)$ yang kadar kolesterolnya tinggi dengan rata-rata sebelum meminum jus buncis $256,64 \mathrm{mg} / \mathrm{dl}$ dan setelah diberikan jus buncis selama 2 minggu dengan frekuensi 1 hari sebanyak $3 / 4$ gelas terdapat penurunan kadar kolesterol responden. Rata-rata kadar kolesterol setelah diberikan jus buncis 163,91 $\mathrm{mg} / \mathrm{dl}$ dengan nilai minimum $136 \mathrm{mg} / \mathrm{dl}$ dan maxmimum 203 mg/dl. Hal ini dikarenakan kadar kolesterol pada responden terlalu tinggi. Dalam penelitian ini kadar kolesterol responden cenderung naik turun, hal ini disebabkan karena banyak faktor antara lain : pola makan yang tidak teratur, olahraga tidak teratur bahkan kecapean juga dapat membuat kadar kolesterol naik turun. Mengkonsumsi jus buncis secara rutin setiap hari juga dapat menjadi suatu cara yang efektif dalam mengontrol kadar kolesterol.

Hasil yang diperoleh dari pengolahan data dengan menggunakan spss didapatkan hasil 0,003 $(\mathrm{p}<0,05)$. Hal ini menunjukkan bahwa adanya Pengaruh Pemberian Jus Buncis Terhadap Penurunan Kadar Kolesterol Di Puskesmas Benda Baru Kota Tangerang Selatan. Dari penjelasan diatas dapat disimpulkan bahwa $\mathrm{Ha}$ diterima dan $\mathrm{HO}$ ditolak yang berarti adanya Pengaruh pemberian jus buncis terhadap penurunan kadar kolesterol.

Hal ini sejalan dengan teori menurut Aniatul, 2018 buncis mengandung niacin sebesar 0,8 $\mathrm{mg}$ atau lebih dikenal dengan vitamin B3 dan serat sebesar 3,4 gram. Vitamin B3 ini sangat penting dalam metabolisme karbohidrat tubuh sehingga memberikan khasiat untuk menurunkan salah satu kadar kolesterol. 


\section{KESIMPULAN}

Teridentifikasi karakteristik responden yaitu rata-rata berusia 46-55 tahun, jenis kelamin terbanyak adalah perempuan, sebelum mengkonsumsi jus buncis terdapat 4 responden (36,4\%) yang berada dikategori batas tinggi dan 7 responden $(63,6 \%)$ yang mengalami kolesterol tinggi, setelah mengkonsumsi jus buncis secara keseluruhan mengalami penurunan, namun hanya sebagian besar responden dengan kadar kolesterol normal yaitu sebanyak 10 responden $(90,0 \%)$ sedangkan hampir tidak ada responden dengan kadar kolesterol 1 responden $(9,1 \%)$ lainnya masih berada di batas tinggi kolesterol.

Hasil uji willcoxon dapat dilihat nilai $p$ value yang diperoleh adalah 0,003. Kesimpulannya adalah adanya Pengaruh Pemberian Jus Buncis Terhadap Penurunan Kadar Kolesterol Di Puskesmas Benda Baru Kota Tangerang Selatan. Penelitian yang dilakukan selama 14 hari (2 minggu).

Saran dari penelitian ini dapat memanfaatkan hasil penelitian ini sebagai salah satu kajian yang bermanfaat bagi peserta didik serta dapat mengembangkan asuhan keperawatan pada pasien kolesterol tinggi dengan memperhatikan penggunakan terapi non farmakologis melalui tindakan pemberian jus buncis dalam upaya mengontrol kadar kolesterol.

\section{DAFTAR PUSTAKA}

Aniatul, H. 2018. Panduan Lengkap Dan Praktis Budidaya Sayuran Yang Paling Menguntungkan. Garuda Pustaka : Jakarta Timur

Garnadi, Y. 2012. Hidup Nyaman Dengan Hiperkolesterol. PT Agro Media Pustaka : Jakarta

Graha, K, Chairinniza. 2010. 100 Questions \& Answers : Kolesterol. PT Alex Media Komputindo : Jakarta

Herliana, Ersi. 2009. Solusi Sehat Mengatasi Kolesterol tinggi. PT Agromedia : Jakarta Selatan

Irawan, Devi, Veronika. 2016. Pengaruh Ekstrak Daun Kersen (Muntingia Calabura) Terhadap Penurunan Kadar Kolesterol Total Tikus Sprague Dawley Dislipidemia. Universitas Kristen Duta Wacana : Yogyakarta

Maidisya, Rizky. 2013. Uji Efek Ekstrak Etanol 70\% Daging Buah Asam Jawa (Tamarindus Indica L) Terhadap Penurunan Kadar Kolesterol Totl Dan Trigliserida Pada Tikus Jantan (Rattus Norvegicus) Galur Wistar Dengan Dislipidemia. Universitas Muhammadiyah Surakarta

Notoatmodjo, Soekidjo. 2012. Metodologi Penelitian Kesehatan. Jakarta : Rineka Rimbawan, dkk. 2013. Hubungan Antara Konsumsi Pangan Dan Aktivitas Fisik Dengan Kadar Kolesterol Darah Pria Dan Wanita Dewasa Di Bogor. Institut Pertanian Bogor : Bogor

Rukmana, Rahmat H. \& Yudirachman, Herdi H. 2017. Budi Daya, Pascapanen \& Teknik Pengalengan Sayuran Agroindustri Potensial. Lily Publisher : Yogyakarta 
